\title{
Epigenetic silencing of the endothelin-B receptor gene in non-small cell lung cancer
}

\author{
LUCY J. KNIGHT ${ }^{1}$, JOSEPH BURRAGE ${ }^{1}$, SARAH R. BUJAC ${ }^{1}$, CAROLYN HAGGERTY ${ }^{2}$, \\ ALEXANDER GRAHAM ${ }^{2}$, NEIL J. GIBSON ${ }^{1}$, GILLIAN ELLISON ${ }^{1}$, JAMES W. GROWCOTT ${ }^{2}$, \\ A. NIGEL BROOKS ${ }^{3}$, ANDREW M. HUGHES ${ }^{2}$, GEORGE XINARIANOS ${ }^{4}$, GEORGIOS NIKOLAIDIS ${ }^{4}$, \\ JOHN K. FIELD ${ }^{4}$ and TRIANTAFILLOS LILOGLOU ${ }^{4}$
}

\begin{abstract}
${ }^{1}$ R\&D Genetics, ${ }^{2}$ Cancer \& Infection Discovery Medicine, ${ }^{3}$ Discovery Bioscience, AstraZeneca, Alderley Park, Macclesfield, SK10 4TF, UK; ${ }^{4}$ Roy Castle Lung Cancer Research Programme, The University of Liverpool Cancer Research Centre Roy Castle Building, The University of Liverpool, 200 London Road, Liverpool, L3 9TA, UK
\end{abstract}

Received October 13, 2008; Accepted November 17, 2008

DOI: 10.3892/ijo_00000171

\begin{abstract}
Endothelin-1 is overexpressed in several tumor types. Activation of the endothelin- $\mathrm{A}\left(\mathrm{ET}_{\mathrm{A}}\right)$ receptor may promote cell growth, angiogenesis and invasion, and inhibits the apoptotic process, while activation of the endothelin-B $\left(\mathrm{ET}_{\mathrm{B}}\right)$ receptor may induce cell death by apoptosis and inhibit tumor progression. Hypermethylation and subsequent silencing of the $\mathrm{ET}_{\mathrm{B}}$ receptor gene promoter has been reported in some cancer types. As the endothelin pathway is subject to research for pharmacological cancer treatment, we investigated the extent of epigenetic deregulation of the $\mathrm{ET}_{\mathrm{B}}$ receptor gene in non-small cell lung cancer (NSCLC). We scanned 64 NSCLC paired tumor/normal surgical specimens for the $\mathrm{ET}_{\mathrm{B}}$ receptor promoter for methylation by developing four pyrosequencing assays that covered $24 \mathrm{CpGs}$. The $\mathrm{ET}_{\mathrm{B}}$ receptor promoter was significantly hypermethylated in 31 $(48 \%)$ of tumor samples, presenting considerably higher methylation in $22 / 24 \mathrm{CpG}$ sites compared with the normal counterpart tissues. $\mathrm{ET}_{\mathrm{B}}$ receptor mRNA levels were reduced in all lung tumors compared with normal adjacent lung tissue, indicating the potentially important involvement of this gene in lung cancer development. Furthermore, tumor samples with $\mathrm{ET}_{\mathrm{B}}$ receptor gene methylation tended to have lower receptor mRNA levels compared with unmethylated tumor specimens, suggesting a primary epigenetic role in $\mathrm{ET}_{\mathrm{B}}$ receptor silencing. Our results point to a significant
\end{abstract}

Correspondence to: Dr Lucy Knight, Quintiles Global Oncology \& ID, Station House, Market Street, Bracknell, Berkshire RG12 $1 \mathrm{HX}, \mathrm{UK}$

E-mail: lucy.knight@quintiles.com

Key words: endothelin-1, non-small cell lung cancer, endothelin-A receptor, endothelin-B receptor, gene methylation involvement of $\mathrm{ET}_{\mathrm{B}}$ receptor epigenetic deregulation in the pathogenesis of lung cancer making the gene a promising candidate biomarker for response to regimens modulating the endothelin axis.

\section{Introduction}

Endothelin-1 is a 21-amino acid vasoactive peptide that plays an important role in the development and progression of many cancer types (1). Endothelin-1 is overexpressed in several tumor types, including those of the lung, where it is associated with poor prognosis (2,3). Binding of endothelin-1 to the G-protein-coupled endothelin-A $\left(\mathrm{ET}_{\mathrm{A}}\right)$ and -B $\left(\mathrm{ET}_{\mathrm{B}}\right)$ receptors on the cell surface results in distinct and opposing effects on cell growth and survival. In most cells, activation of the $\mathrm{ET}_{\mathrm{A}}$ receptor promotes cell growth, angiogenesis and invasion, and inhibits the apoptotic process (4), whereas, in contrast, activation of the ETB receptor induces cell death by apoptosis and thus inhibits tumor progression (5). Additionally, the $\mathrm{ET}_{\mathrm{B}}$ receptor mediates clearance of endothelin-1 (6), suggesting that $\mathrm{ET}_{\mathrm{B}}$ receptor blockade may increase circulating levels of endothelin-1, resulting in competition for $\mathrm{ET}_{\mathrm{A}}$ receptor binding between receptor antagonists and excess endothelin-1. This, in turn, may lead to increasing activation of the $\mathrm{ET}_{\mathrm{A}}$ receptor.

Any mechanism, therefore, that results in a reduction of $\mathrm{ET}_{\mathrm{B}}$ receptor expression may drive tumor progression by favoring cell survival. DNA methylation at cytosine-guanine $(\mathrm{CpG})$ dinucleotides is a key epigenetic event involved in normal genetic processes including DNA repair, chromosome stability, telomere maintenance and transcriptional control (7). It is now well established that the DNA methylation profile of human tumors is fundamentally distorted by a combination of a global genome hypomethylation, and specific $\mathrm{CpG}$ island hypermethylation $(8,9)$. Frequently, this $\mathrm{CpG}$ island hypermethylation occurs within the promoter regions of genes whose function is crucial for genome stability and growth control, including genes for DNA damage response, cell cycle arrest and apoptosis $(9,10)$. Numerous studies have 


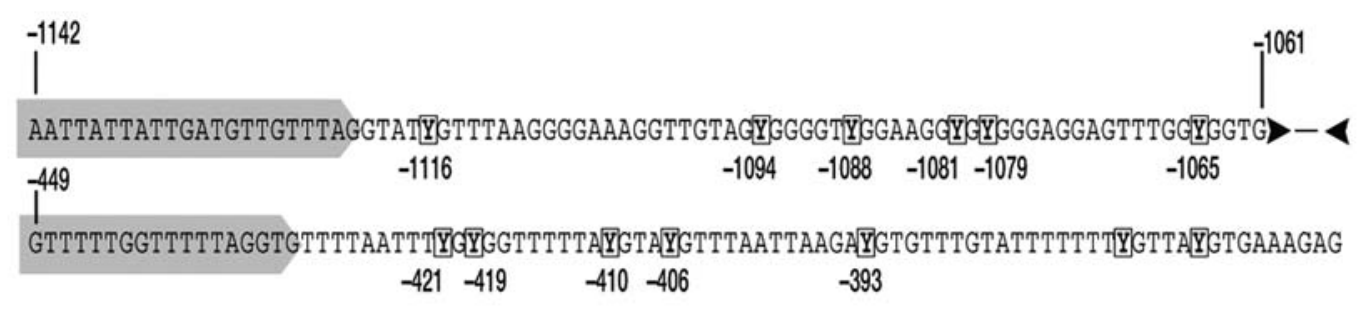

TTYYGGAGTTTTGTTTGGGATTTTATTATTTTTTTTTGGTATATTTTTTTAGAAYGTTYYYGTTTATTGTATATTATTTATTTTT

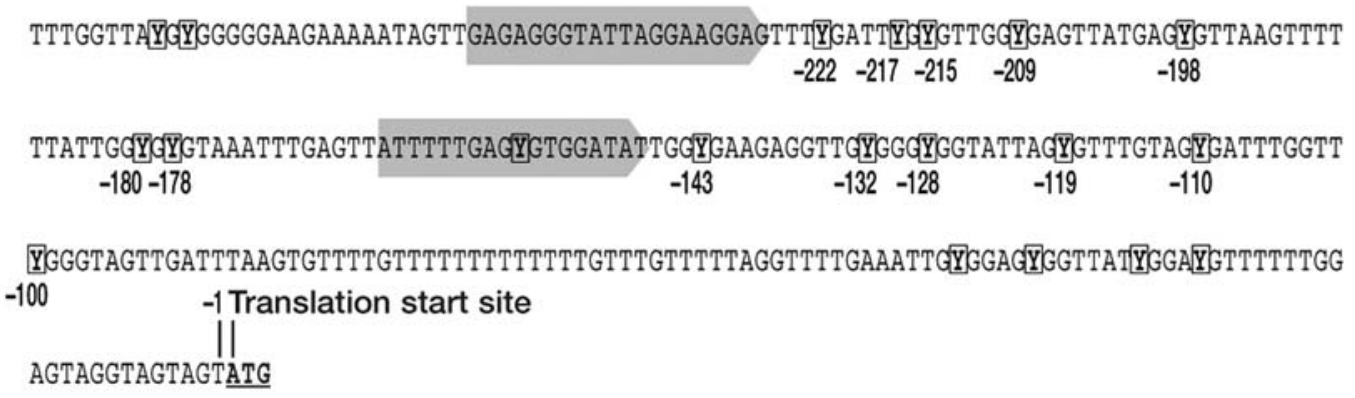

Figure 1. Bisulfite treated $\mathrm{ET}_{\mathrm{B}}$ receptor gene promoter sequence. Potentially methylated cytosine nucleotides (Y) are highlighted. Gray arrows indicate the location of each sequencing primer and the assay direction.

reported epigenetic silencing of such genes in human cancers, with frequent reports of tumor samples carrying abnormal DNA methylation in multiple genes, suggestive of a CpG methylator tumor phenotype (11-14).

Among all human neoplasias, lung cancer has a unique combination of high incidence and mortality that makes it the leading cause of cancer-related deaths worldwide (15). Abnormal epigenetic reprogramming in lung cancer has been investigated extensively, with studies showing a large number of hypermethylated genes (16-21). Of particular importance is the fact that abnormal DNA methylation has been detected in clinical specimens, such as plasma, sputum and bronchial lavage fluid from patients with lung cancer (22-27), suggesting a potential use of DNA methylation biomarkers in early detection and screening strategies (28).

Hypermethylation of the $\mathrm{ET}_{\mathrm{B}}$ receptor gene promoter and resultant silencing of gene expression has been reported in nasopharyngeal (29) and prostate tumors (3) and melanoma cell lines (30). Using Southern blot analysis, Nelson and coworkers found aberrant $\mathrm{ET}_{\mathrm{B}}$ receptor gene hypermethylation in $70 \%$ of prostate tumors, while no methylation was detected in morphologically normal tissue (31). Likewise, studies using real-time quantitative methylation-specific polymerase chain reaction (MS-PCR) found only low levels of hypermethylation in prostate tumor specimens and no methylation in normal tissue $(32,33)$. The reasons for this discordance are unclear.

In contrast, other studies using MS-PCR assays have found a similarly high frequency of $\mathrm{ET}_{\mathrm{B}}$ receptor gene hypermethylation in specimens taken from prostate tumor, benign prostatic hypertrophy, and paired morphologically normal tissue $(3,34)$. Methylation data from human lung cancer is limited. There has only been one previous study of $\mathrm{ET}_{\mathrm{B}}$ receptor gene hypermethylation in lung cancer, in which methylation was detected in 26 out of 79 patients $(33 \%)$ (6). To clarify the extent of epigenetic deregulation of the $\mathrm{ET}_{\mathrm{B}}$ receptor gene in non-small cell lung cancer (NSCLC), we analyzed methylation levels of the $\mathrm{CpG}$ island located in the promoter region of the $\mathrm{ET}_{\mathrm{B}}$ receptor gene in 64 lung tumor samples and compared them with methylation levels in adjacent normal tissue control specimens.

\section{Materials and methods}

$E T_{B}$ receptor gene methylation. This study was carried out in accordance with ethics review board approval and all patients gave written informed consent. Frozen NSCLC tumor and matched adjacent normal control samples were obtained from 64 patients in two panels. Panel 1 consisted of 48 patients [22 female, 26 male; mean age 65 years (range, 45-82)] with NSCLC recruited at the Broadgreen Cardiothoracic Centre (University of Liverpool Cancer Research Centre, Liverpool, UK). All tumor specimens were of advanced stage (T2, $\mathrm{n}=44 ; \mathrm{T} 3, \mathrm{n}=4$ ) and were paired to normal adjacent tissue. Twenty-four patients $(50 \%)$ had a histological diagnosis of adenocarcinoma; the other 24 patients $(50 \%)$ had a diagnosis of squamous cell carcinoma.

Panel 2 consisted of 16 patients [ 1 female, 15 male; mean age 63 years (range 51-73)] with NSCLC recruited at Asterand PLC (Royston, Hertfordshire, UK) and GE Healthcare (Little Chalfont, Buckinghamshire, UK). Samples were of mixed stage (T1-T3). Nine patients had a histological diagnosis of adenocarcinoma, 3 of squamous cell carcinoma, and 4 were not classified.

Tissue samples were frozen immediately after biopsy and stored at $-80^{\circ} \mathrm{C}$. Tumor specimens were mounted and $6 \mu \mathrm{m}$ sections were obtained and stained with hematoxylin and 


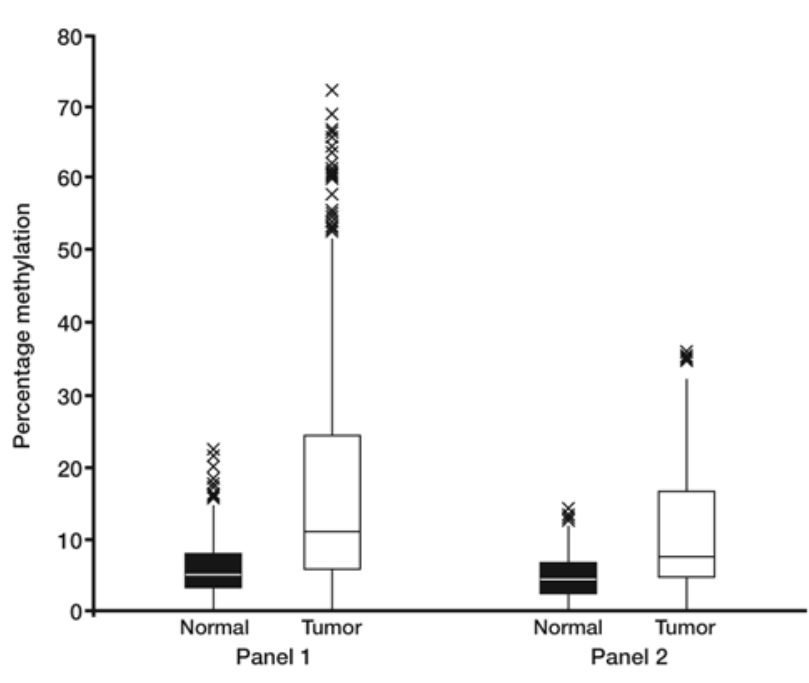

Figure 2. Summary statistics for percentage methylation over $24 \mathrm{CpG}$ sites of the $\mathrm{ET}_{\mathrm{B}}$ receptor gene, according to panel and tissue type. Each box represents the range from the 25th to 75 th percentile. The vertical lines extend to 1.5 interquartile range, and values outside this are shown as crosses. Horizontal lines represent the median. The results from one normal sample were excluded from Panel 1, due to assay failure.

eosin. DNA was extracted using the DNeasy Blood \& Tissue Kit (Qiagen, Crawley, UK) and underwent sodium bisulfite treatment using the EZ DNA Methylation-Gold Kit ${ }^{\mathrm{TM}}$ (Zymo Research, CA, USA).

For analysis of $\mathrm{ET}_{\mathrm{B}}$ receptor gene methylation, pyrosequencing assays spanning $24 \mathrm{CpG}$ sites were developed using the primers shown in Fig. 1. As far as possible, the primers were designed to flank $\mathrm{CpG}$ sites of interest so that the PCR products accurately represented the methylation status of the source DNA. The pyrosequencing reactions were undertaken using the SQA-Gold kit (Biotage, Uppsala, Sweden) and quantitative, reproducible methylation data across the $\mathrm{ET}_{\mathrm{B}}$ receptor gene $\mathrm{CpG}$ island were obtained using pyrosequencing with the Pyro Q-CpG ${ }^{\mathrm{TM}}$ software package (Biotage).

$E T_{B}$ receptor expression. Tissue of suitable quality for $\mathrm{ET}_{\mathrm{B}}$ receptor expression analysis was available from 11 lung tumors (5 with methylated receptor genes and 6 with unmethylated receptor genes) from Panel 2. The specimens were thawed at $-20^{\circ} \mathrm{C}$ in RNAlater ${ }^{\circledR}$ ice (Ambion, TX, USA) and homogenized with the TissueLyser Mixer Mill MM 300 (Qiagen) in RLT buffer (Qiagen) containing B-mercaptoethanol for $6 \mathrm{~min}$ at $20 \mathrm{~Hz}$. RNA was extracted from the 11 tumor samples and 4 normal lung tissue samples, and digested using the RNeasy Mini Kit and Rnase-free DNase set (Qiagen) and was quantified using a NanoDrop ND-1000 Spectrophotometer (LabTech International, Ringmer, UK). Samples were adjusted to $100 \mathrm{ng} / \mu 1$.

Total RNA quality was assessed using Agilent's 2100 Bioanalyser Instrument with the RNA 6000 Nano Assay (Agilent, CA, USA). A TaqMan ${ }^{\circledR}$ Low Density Array Endogenous Control Panel (Applied Biosystems, CA, USA) was run on the ABI Prism 7900HT Sequence Detection System (Applied Biosystems) and the two most appropriate endogenous control assays UBC (HS00824723_m1) and B2M (HS99999907_m1) were selected using the geNorm macro software (Ghent University, Ghent, Belgium) for Microsoft Excel (Microsoft Corporation, USA). Real-time quantitative PCR was carried out using a TaqMan ${ }^{\circledR}$ Gene Expression Assay (Applied Biosystems) for the $\mathrm{ET}_{\mathrm{B}}$ receptor (Hs0024 0747_m1). The relative quantification of $\mathrm{ET}_{\mathrm{B}}$ receptor expression was calculated using the comparative $\mathrm{Ct}$ method, where $\Delta \mathrm{Ct}$ is $\mathrm{Ct}\left(\mathrm{ET}_{\mathrm{B}}\right.$ receptor) - $\mathrm{Ct}$ (control). The $\Delta \mathrm{Ct}$ values were used to calculate $2^{-\Delta \Delta C t}$.

Statistical analysis. The Wilcoxon signed rank test was used to assess the differences in receptor gene methylation between tumor and normal tissue samples at each $\mathrm{CpG}$ site. Although the study was designed with individually matched tumor and normal samples, the distribution of the paired differences in percentage methylation between the tumor and normal samples was highly skewed. As a result, the Wilcoxon nonparametric test was preferred to a paired Student's t-test. Minimal loss of power was expected from selecting a nonpaired analysis method because the variation between the normal samples was relatively low.

Heatmaps and line graphs were used to visualize the receptor gene methylation patterns across all $\mathrm{CpG}$ sites. In order to allow comparison of all tumor and normal tissue samples from the two panels, values in the two datasets were normalized by subtracting the mean methylation value from the raw methylation value and dividing the result by the standard deviation for that panel.

Spearman rank correlation was used to determine the relationship between $\mathrm{ET}_{\mathrm{B}}$ receptor gene methylation and relative $\mathrm{ET}_{\mathrm{B}}$ receptor expression in the 11 lung tumor specimens available for RNA extraction.

The frequency of hypermethylated tumor samples in each panel was calculated by counting the number of samples that had a mean methylation value (mean across all $24 \mathrm{CpG}$ sites) greater than the mean +3 standard deviations of all the matched normal mean methylation values, and dividing by the total number of tumor samples. All calculations were conducted on a log scale. The difference in hypermethylation frequency between tumor and normal samples was tested using Fisher's exact test.

\section{Results}

$E T_{B}$ receptor gene methylation. In both patient panels, the proportion of samples showing $\mathrm{ET}_{\mathrm{B}}$ receptor gene hypermethylation was significantly higher in tumors compared with the corresponding normal tissues [25/48 versus $1 / 48$, respectively, for Panel $1(\mathrm{P}<0.001)$ and $6 / 16$ versus $0 / 16$, respectively, for Panel 2 ( $\mathrm{P}=0.03)$; Fig. 2]. It was of note that the relative methylation of the 24 individual $\mathrm{CpG}$ sites varied within samples creating patterns. Normalized individual methylation profiles across the two panels are shown in Fig. 3. When comparing methylation of individual CpGs, 22 of the $24 \mathrm{CpG}$ sites demonstrated significantly higher levels in tumor specimens (Table I). A heatmap visualization of the $\mathrm{ET}_{\mathrm{B}}$ receptor gene methylation data (Fig. 4) showed that the tumor tissues exhibited a variety of promoter region methylation patterns. Broadly, there 


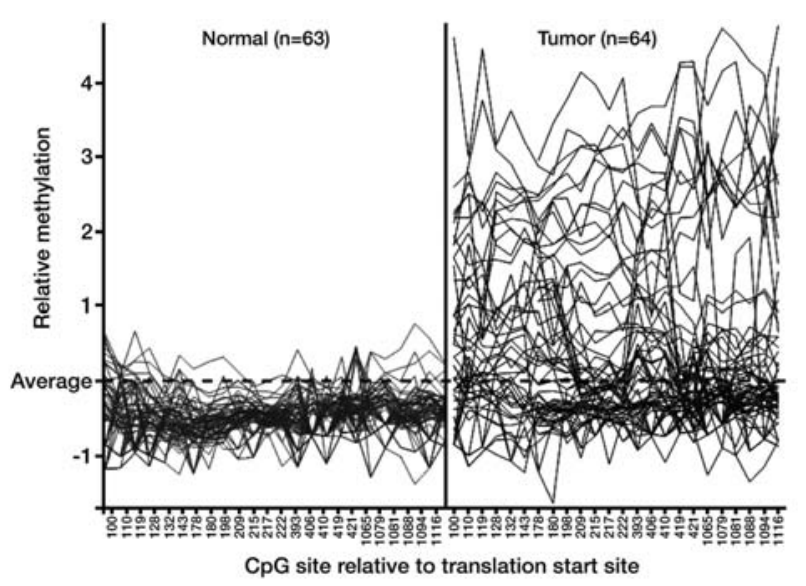

Figure 3. Individual methylation profiles normalized across the two panels. were four categories: a) consistently high methylation across all $24 \mathrm{CpG}$ sites; b) consistently moderate methylation; c) variable methylation across the $24 \mathrm{CpG}$ sites, resulting in a moderate overall level of methylation; and d) consistently low methylation.

We have screened, as an additional control, DNA from the peripheral blood of 16 healthy individuals. The level of methylation in all these samples was similar to that of normal adjacent lung.

$E T_{B}$ receptor expression. With the exception of one tumor tissue sample (sample number 11 ), $\mathrm{ET}_{\mathrm{B}}$ receptor mRNA levels were reduced in all lung tumors compared with normal lung tissue, indicating a clear relationship between tissue type and receptor expression (Fig. 5).

Table I. Median percentage methylation at each $\mathrm{ET}_{\mathrm{B}}$ receptor gene $\mathrm{CpG}$ site in normal tissue controls and NSCLC tumor specimens.

\begin{tabular}{|c|c|c|c|c|c|c|c|c|}
\hline \multirow[b]{3}{*}{ CpG site } & \multicolumn{4}{|c|}{ Panel 1} & \multicolumn{4}{|c|}{ Panel 2} \\
\hline & \multicolumn{2}{|c|}{$\begin{array}{c}\text { Normal } \\
(n=47)\end{array}$} & \multicolumn{2}{|c|}{$\begin{array}{l}\text { Tumor } \\
(\mathrm{n}=48)\end{array}$} & \multicolumn{2}{|c|}{$\begin{array}{l}\text { Normal } \\
(n=16)\end{array}$} & \multicolumn{2}{|c|}{$\begin{array}{l}\text { Tumor } \\
(n=16)\end{array}$} \\
\hline & Median & Range & Median & Range & Median & Range & Median & Range \\
\hline 100 & 5 & $0-17$ & $16^{\mathrm{a}}$ & $0-67$ & 5 & $0-11$ & $8^{\mathrm{b}}$ & $4-22$ \\
\hline 110 & 5 & $0-12$ & $16^{\mathrm{a}}$ & $0-43$ & 5 & $0-9$ & $8^{c}$ & $0-25$ \\
\hline 119 & 5 & $0-18$ & $15^{\mathrm{a}}$ & $0-64$ & 3 & $0-6$ & $7^{\mathrm{b}}$ & $0-21$ \\
\hline 128 & 6 & $0-18$ & $19^{a}$ & $5-55$ & 6 & $0-11$ & $11^{\mathrm{b}}$ & $3-35$ \\
\hline 132 & 8 & $0-15$ & $23^{\mathrm{a}}$ & $0-66$ & 7 & $4-12$ & $14^{\mathrm{b}}$ & $6-36$ \\
\hline 143 & 9 & $0-21$ & $26^{a}$ & $9-62$ & 8 & $5-14$ & $14^{\mathrm{c}}$ & $4-35$ \\
\hline 178 & 9 & $0-20$ & $22^{\mathrm{a}}$ & $0-62$ & 7 & $6-13$ & $15^{\mathrm{a}}$ & $6-35$ \\
\hline 180 & 13 & $6-22$ & $22^{\mathrm{a}}$ & $11-61$ & 9 & $7-12$ & $14^{\mathrm{a}}$ & $9-32$ \\
\hline 198 & 9 & $4-20$ & $18^{\mathrm{a}}$ & $6-66$ & 8 & $6-13$ & $14^{\mathrm{b}}$ & $6-35$ \\
\hline 209 & 5 & $0-12$ & $10^{\mathrm{a}}$ & $0-60$ & 4 & $0-6$ & $6^{\mathrm{b}}$ & $0-25$ \\
\hline 215 & 4 & $0-8$ & $8^{a}$ & $0-62$ & 3 & $0-6$ & $5^{\mathrm{a}}$ & $3-24$ \\
\hline 217 & 8 & $5-15$ & $14^{\mathrm{a}}$ & $6-73$ & 4 & $2-6$ & $7^{\mathrm{a}}$ & $0-28$ \\
\hline 222 & 5 & $0-12$ & $9^{a}$ & $0-67$ & 3 & $0-6$ & $7^{\mathrm{a}}$ & $3-25$ \\
\hline 393 & 8 & $0-14$ & $17^{\mathrm{a}}$ & $5-61$ & 0 & $0-11$ & $10^{\mathrm{b}}$ & $0-27$ \\
\hline 406 & 0 & $0-9$ & $11^{\mathrm{a}}$ & $0-58$ & 0 & $0-7$ & $6^{b}$ & $0-23$ \\
\hline 410 & 4 & $0-9$ & $11^{\mathrm{a}}$ & $0-60$ & 5 & $0-8$ & $9^{b}$ & $0-25$ \\
\hline 419 & 4 & $0-8$ & $6^{a}$ & $2-54$ & 2 & $0-5$ & 3 & $0-21$ \\
\hline 421 & 5 & $0-14$ & $7^{\mathrm{a}}$ & $0-56$ & 0 & $0-5$ & 4 & $0-17$ \\
\hline 1065 & 4 & $0-11$ & $7^{\mathrm{a}}$ & $0-52$ & 4 & $0-7$ & $5^{\mathrm{b}}$ & $3-19$ \\
\hline 1079 & 0 & $0-7$ & $4^{\mathrm{a}}$ & $0-43$ & 2 & $0-4$ & $4^{\mathrm{b}}$ & $0-18$ \\
\hline 1081 & 4 & $0-11$ & $7^{\mathrm{a}}$ & $0-46$ & 3 & $2-6$ & $5^{\mathrm{b}}$ & $0-25$ \\
\hline 1088 & 5 & $0-16$ & $8^{a}$ & $0-50$ & 5 & $3-9$ & $8^{\mathrm{b}}$ & $4-25$ \\
\hline 1094 & 3 & $0-11$ & $6^{\mathrm{a}}$ & $0-41$ & 3 & $0-7$ & $5^{b}$ & $2-18$ \\
\hline 1116 & 3 & $0-8$ & $5^{\mathrm{a}}$ & $0-41$ & 3 & $0-5$ & $4^{c}$ & $0-27$ \\
\hline
\end{tabular}

${ }^{\mathrm{a}} \mathrm{P}<0.001$ versus normal; ${ }^{\mathrm{b}} \mathrm{P}<0.01$ versus normal; ${ }^{\mathrm{c}} \mathrm{P}<0.05$ versus normal. 


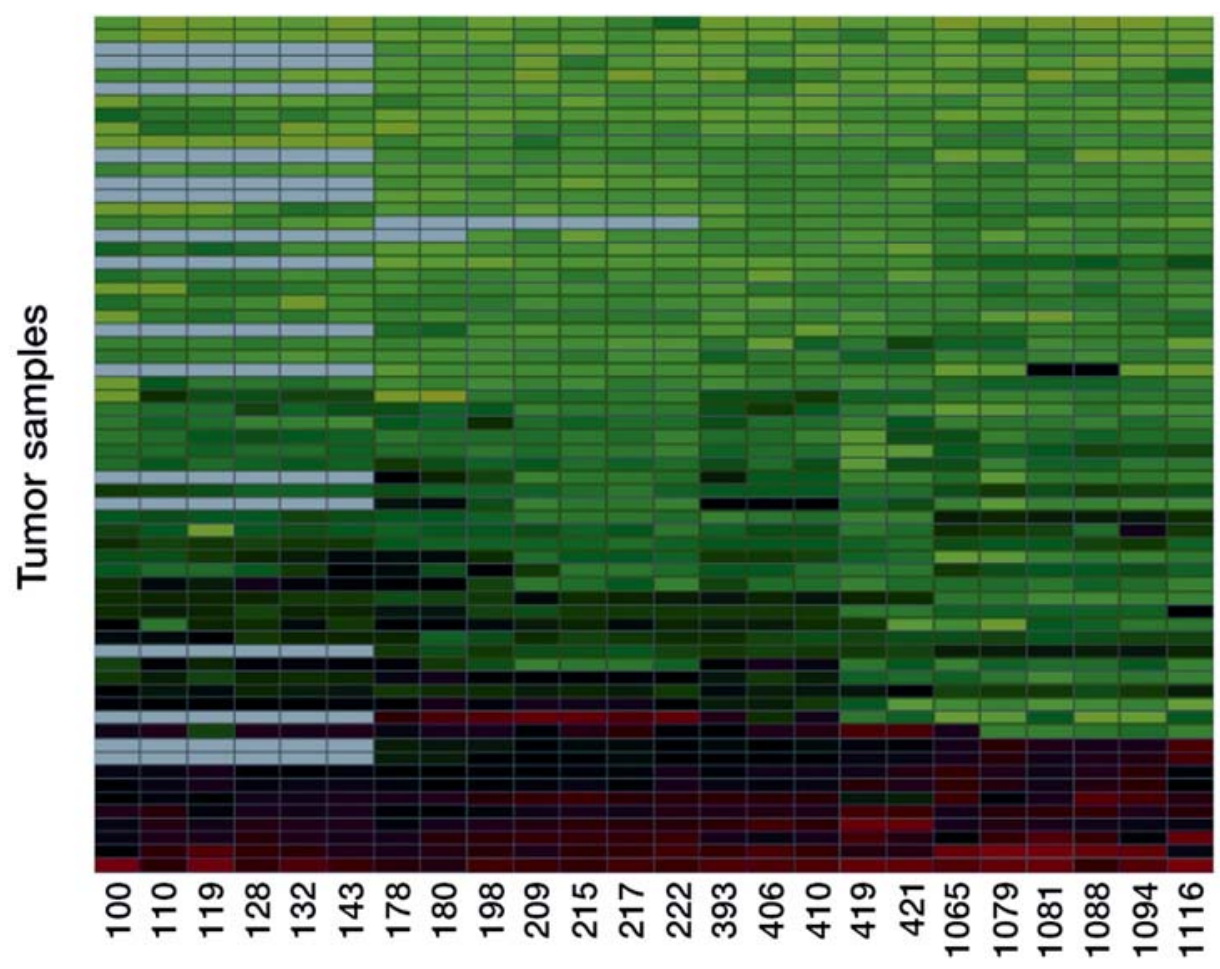

Colors: default $-1.64$ CpG site relative to translation start site

Figure 4. Heatmap visualization of normalized $\mathrm{ET}_{\mathrm{B}}$ receptor gene promoter methylation in tumor samples. Each column represents one $\mathrm{CpG}$ site and each row represents one tumor sample. Red indicates hypermethylation; green indicates absence of methylation; gray indicates no data. Samples are ranked by increasing average methylation across all $\mathrm{CpG}$ sites.

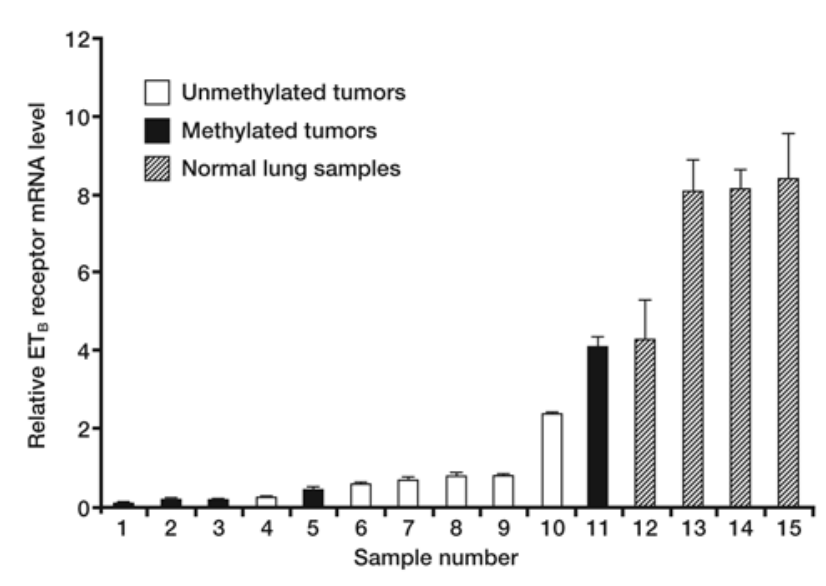

Figure 5. Relative $\mathrm{ET}_{\mathrm{B}}$ receptor mRNA levels in unmethylated tumors methylated tumors and normal lung samples. Samples are ranked by increasing relative receptor expression.

Within the tumor specimens, samples with $\mathrm{ET}_{\mathrm{B}}$ receptor gene methylation demonstrated lower receptor mRNA levels compared with unmethylated tumor specimens (Spearman rank correlation coefficient, $-0.63 ; \mathrm{P}=0.039$ ).

No association was observed between hypermethylation and histology, nodal metastasis, or differentiation in Panel 1, while no such data was available for Panel 2.

\section{Discussion}

In view of its potential implication on endothelin axis-based cancer treatments, we investigated the extent of epigenetic deregulation of the $\mathrm{ET}_{\mathrm{B}}$ receptor gene. More specifically, we scanned the $\mathrm{CpG}$ island located in the promoter region, in order to map its methylation pattern in NSCLC. We demonstrated a significant aberrant methylation across the $\mathrm{ET}_{\mathrm{B}}$ receptor gene promoter region, suggesting methylation plays an important role in lung tumorigenesis. Hypermethylation of the $\mathrm{ET}_{\mathrm{B}}$ receptor has been also described in prostate $(31,35,36)$, nasopharyngeal (29), bladder (37) and renal (38) tumors, while there is a single previous report for lung cancer (6). This indicates that epigenetic deregulation of the $\mathrm{ET}_{\mathrm{B}}$ receptor is most probably a common feature of many epithelial tumor types. There was no difference in hypermethylation observed between histological types, namely adenocarcinomas and squamous cell carcinomas, which contradicts the previous report (6). A larger confirmatory study is required to confirm the absence or presence of such a difference.

It is of note that methylation levels across the promoter were frequently subject to significant differences creating specific methylation patterns that can be visualized in the heatmap analysis (Fig. 4). The significance of the different patterns of methylation observed in tumors is not yet understood. While some tumors showed consistently high levels 
of methylation, which may be expected to lead to downregulation of $\mathrm{ET}_{\mathrm{B}}$ receptor expression, others showed variable, moderate, or even low levels of methylation across all $\mathrm{CpG}$ sites. The variable methylation patterns observed in some tumor samples may therefore lead to incorrect assignment in analyses based on a small number of representative $\mathrm{CpG}$ sites. These data highlight the importance of quantitative, comprehensive analysis of $\mathrm{CpG}$ sites across the promoter region, prior to design of a targeted assay.

In this study, tissue of sufficient quality for RNA extraction was only available from a small subset of samples. Nevertheless, $\mathrm{ET}_{\mathrm{B}}$ receptor mRNA levels were significantly lower in tumors with methylated gene promoters compared with tumors with unmethylated gene promoters. These results demonstrate for the first time in lung tumors the $\mathrm{ET}_{\mathrm{B}}$ receptor gene epigenetic repression of transcription, confirming previous findings in lung tumor cell lines (6). This is important not only because $\mathrm{ET}_{\mathrm{B}}$ receptor gene methylation is implicated in the pathogenesis of lung cancer, but also because patients with methylation and resultant loss of receptor expression may respond differently to treatment with $\mathrm{ET}_{\mathrm{A}}$ receptor antagonists.

Absence of the active form of the $\mathrm{ET}_{\mathrm{B}}$ receptor reduces the opportunity for apoptotic signaling elicited by activation of the $\mathrm{ET}_{\mathrm{B}}$ receptor. Moreover, downregulation of the $\mathrm{ET}_{\mathrm{B}}$ receptor may prevent internalization and removal of endothelin-1. In the tumor cell environment, this lack of compensatory apoptotic influence coupled with an inability to remove endothelin-1 from the circulation may permit unabated activation of the $\mathrm{ET}_{\mathrm{A}}$ receptor, leading to increased cell survival, proliferation and invasion. Thus, tumors with hypermethylated $\mathrm{ET}_{\mathrm{B}}$ receptor gene promoter regions may be more aggressive and progressive, and lead to metastatic disease more quickly than those tumors where such hypermethylation is absent.

The highest levels of endothelin-1 expression have been recorded around tumor vasculature and in tumor tissue specimens from patients with $\operatorname{NSCLC}(2,39)$. While endothelin-1 expression has been demonstrated in all lung cancer types, the highest levels have been observed in adenocarcinoma and squamous cell carcinoma $(40,41)$, the type analyzed in our study. Hence, in tumors where $\mathrm{ET}_{\mathrm{B}}$ receptor gene hypermethylation prevails, this may lead to an increased local concentration of endothelin-1, which will drive the survival of that tumor via unabated activation of the $\mathrm{ET}_{\mathrm{A}}$ receptors.

The role of $\mathrm{ET}_{\mathrm{B}}$ receptor gene hypermethylation in response to treatment with endothelin receptor antagonists is currently unclear. However, one may hypothesize that patients with an unmethylated $\mathrm{ET}_{\mathrm{B}}$ receptor gene could gain a clinical benefit as blocking the $\mathrm{ET}_{\mathrm{A}}$ receptor would redirect signaling via a still-active pro-apoptotic pathway mediated by the $\mathrm{ET}_{\mathrm{B}}$ receptor. On the other hand, patients with a methylated $\mathrm{ET}_{\mathrm{B}}$ receptor gene would receive the majority of their endothelin-1 signaling in tumor tissue via the $\mathrm{ET}_{\mathrm{A}}$ receptor pathway. Inhibition of that pathway may therefore have a more dramatic impact on disease progression in patients with a methylated $\mathrm{ET}_{\mathrm{B}}$ receptor. The role of $\mathrm{ET}_{\mathrm{B}}$ receptor gene hypermethylation is currently being explored in cell lines and in clinical trials in patients receiving treatment with a specific $\mathrm{ET}_{\mathrm{A}}$ receptor antagonist.

\section{Acknowledgments}

J.K.F., G.N., G.X. and T.L. have received funding from Roy Castle Lung Cancer Foundation. A.N.B., J.W.G., N.J.G., A.G., C.H., L.J.K. and G.E. were employed by AstraZeneca at the time this study was conducted. J.W.G. and N.J.G. have ownership interests in AstraZeneca. We thank Adam McGechan of Mudskipper Bioscience for medical writing support on behalf of AstraZeneca.

\section{References}

1. Bagnato A and Natali PG: Endothelin receptors as novel targets in tumor therapy. J Transl Med 2: 16, 2004.

2. Arun C, DeCatris M, Hemingway DM, London NJ and O'Byrne KJ: Endothelin-1 is a novel prognostic factor in nonsmall cell lung cancer. Int J Biol Markers 19: 262-267, 2004.

3. Jerónimo C, Henrique R, Campos PF, Oliveira J, Caballero OL, Lopes C and Sidransky D: Endothelin B receptor gene hypermethylation in prostate adenocarcinoma. J Clin Pathol 56: 52-55, 2003.

4. Nelson J, Bagnato A, Battistini B and Nisen P: The endothelin axis: emerging role in cancer. Nat Rev Cancer 3: 110-116, 2003.

5. Morris CD, Rose A, Curwen J, Hughes AM, Wilson DJ and Webb DJ: Specific inhibition of the endothelin A receptor with ZD4054: clinical and pre-clinical evidence. Br J Cancer 92: 2148-2152, 2005

6. Chen SC, Lin CY, Chen YH, Fang HY, Cheng CY, Chang CW, Chen RA, Tai HL, Lee CH, Chou MC, Lin TS and Hsu LS: Aberrant promoter methylation of EDNRB in lung cancer in Taiwan. Oncol Rep 15: 167-172, 2006.

7. Esteller M: Epigenetic gene silencing in cancer: the DNA hypermethylome. Hum Mol Genet 16 Spec No 1: R50-R59, 2007.

8. Jones PA: The DNA methylation paradox. Trends Genet 15: 34-37, 1999.

9. Baylin SB and Ohm JE: Epigenetic gene silencing in cancer a mechanism for early oncogenic pathway addiction? Nat Rev Cancer 6: 107-116, 2006.

10. Brena RM and Costello JF: Genome-epigenome interactions in cancer. Hum Mol Genet 16 Spec No 1: R96-R105, 2007.

11. Issa JP: CpG island methylator phenotype in cancer. Nat Rev Cancer 4: 988-993, 2004.

12. Shaw RJ, Hall GL, Lowe D, Bowers NL, Liloglou T, Field JK, Woolgar JA and Risk JM: CpG island methylation phenotype (CIMP) in oral cancer: associated with a marked inflammatory response and less aggressive tumour biology. Oral Oncol 43: 878-886, 2007

13. O'Brien MJ, Yang S, Mack C, Xu H, Huang CS, Mulcahy E, Amorosino $\mathrm{M}$ and Farraye FA: Comparison of microsatellite instability, CpG island methylation phenotype, BRAF and KRAS status in serrated polyps and traditional adenomas indicates separate pathways to distinct colorectal carcinoma end-points. Am J Surg Pathol 30: 1491-1501, 2006.

14. Marsit CJ, Houseman EA, Christensen BC, Eddy K, Bueno R, Sugarbaker DJ, Nelson HH, Karagas MR and Kelsey KT: Examination of a $\mathrm{CpG}$ island methylator phenotype and implications of methylation profiles in solid tumors. Cancer Res 66: 10621-10629, 2006.

15. Jemal A, Siegel R, Ward E, Murray T, Xu J and Thun MJ: Cancer Statistics, 2007. CA Cancer J Clin 57: 43-66, 2007.

16. Ehrich M, Field JK, Liloglou T, Xinarianos G, Oeth P, Nelson MR, Cantor CR and van den Boom D: Cytosine methylation profiles as a molecular marker in non-small cell lung cancer. Cancer Res 66: 10911-10918, 2006.

17. Ehrich M, Nelson MR, Stanssens P, Zabeau M, Liloglou T, Xinarianos G, Cantor CR, Field JK and van den Boom D: Quantitative high-throughput analysis of DNA methylation patterns by base-specific cleavage and mass spectrometry. Proc Natl Acad Sci USA 102: 15785-15790, 2005.

18. Xinarianos G, McRonald FE, Risk JM, Bowers NL, Nikolaidis G, Field JK and Liloglou T: Frequent genetic and epigenetic abnormalities contribute to the deregulation of cytoglobin in nonsmall cell lung cancer. Hum Mol Genet 15: 2038-2044, 2006. 
19. Field JK, Liloglou T, Warrak S, Burger M, Becker E, Berlin K, Nimmrich I and Maier S: Methylation discriminators in NSCLC identified by a microarray based approach. Int J Oncol 27: $105-111,2005$.

20. Shames DS, Girard L, Gao B, Sato M, Lewis CM, Shivapurkar N, Jiang A, Perou CM, Kim YH, Pollack JR, Fong KM, Lam C-L, Wong M, Shyr Y, Nanda R, Olopade OI, Gerald W, Euhus DM, Shay JW, Gazdar AF and Minna JD: A genome-wide screen for promoter methylation in lung cancer identifies novel methylation markers for multiple malignancies. PLoS Med 3: E486, 2006.

21. Toyooka S, Tokumo M, Shigematsu H, Matsuo K, Asano H Tomii K, Ichihara S, Suzuki M, Aoe M, Date H, Gazdar AF and Shimizu N: Mutational and epigenetic evidence for independent pathways for lung adenocarcinomas arising in smokers and never smokers. Cancer Res 66: 1371-1375, 2006.

22. Shivapurkar N, Stastny V, Suzuki M, Wistuba II, Li L, Zheng Y, Feng Z, Hol B, Prinsen C, Thunnissen FB and Gazdar AF: Application of a methylation gene panel by quantitative PCR for lung cancers. Cancer Lett 247: 56-71, 2007.

23. Belinsky SA, Grimes MJ, Casas E, Stidley CA, Franklin WA, Bocklage TJ, Johnson DH and Schiller JH: Predicting gene promoter methylation in non-small-cell lung cancer by evaluating sputum and serum. Br J Cancer 96: 1278-1283, 2007.

24. Belinsky SA, Klinge DM, Dekker JD, Smith MW, Bocklage TJ, Gilliland FD, Crowell RE, Karp DD, Stidley CA and Picchi MA: Gene promoter methylation in plasma and sputum increases with lung cancer risk. Clin Cancer Res 11: 6505-6511, 2005.

25. Belinsky SA, Liechty KC, Gentry FD, Wolf HJ, Rogers J, Vu K, Haney J, Kennedy TC, Hirsch FR, Miller Y, Franklin WA, Herman JG, Baylin SB, Bunn PA and Byers T: Promoter hypermethylation of multiple genes in sputum precedes lung cancer incidence in a high-risk cohort. Cancer Res 66: 3338-3344, 2006.

26. Cirincione R, Lintas C, Conte D, Mariani L, Roz L, Vignola AM, Pastorino U and Sozzi G: Methylation profile in tumor and sputum samples of lung cancer patients detected by spiral computed tomography: a nested case-control study. Int J Cancer 118: 1248-1253, 2006.

27. Bearzatto A, Conte D, Frattini M, Zaffaroni N, Andriani F, Balestra D, Tavecchio L, Daidone MG and Sozzi G: $\mathrm{p}^{16 \mathrm{INK} 4 \mathrm{~A}}$ Hypermethylation detected by fluorescent methylation-specific PCR in plasmas from non-small cell lung cancer. Clin Cancer Res 8: 3782-3787, 2002.

28. Wang YC, Hsu HS, Chen TP and Chen JT: Molecular diagnostic markers for lung cancer in sputum and plasma. Ann NY Acad Sci 1075: 179-184, 2006.

29. Lo KW, Tsang YS, Kwong J, To KF, Teo PM and Huang DP: Promoter hypermethylation of the EDNRB gene in nasopharyngeal carcinoma. Int J Cancer 98: 651-655, 2002.

30. Eberle J, Weitmann S, Thieck O, Pech H, Paul M and Orfanos CE: Downregulation of endothelin B receptor in human melanoma cell lines parallel to differentiation genes. J Invest Dermatol 112: 925-932, 1999.
31. Nelson JB, Lee WH, Nguyen SH, Jarrard DF, Brooks JD, Magnuson SR, Opgenorth TJ, Nelson WG and Bova GS: Methylation of the $5^{\prime} \mathrm{CpG}$ island of the endothelin $\mathrm{B}$ receptor gene is common in human prostate cancer. Cancer Res 57: 35-37, 1997.

32. Bastian PJ, Ellinger J, Wellmann A, Wernert N, Heukamp LC, Müller SC and von Ruecker A: Diagnostic and prognostic information in prostate cancer with the help of a small set of hypermethylated gene loci. Clin Cancer Res 11: 4097-4106, 2005.

33. Yegnasubramanian S, Kowalski J, Gonzalgo ML, Zahurak M, Piantadosi S, Walsh PC, Bova GS, De Marzo AM, Isaacs WB and Nelson WG: Hypermethylation of $\mathrm{CpG}$ islands in primary and metastatic human prostate cancer. Cancer Res 64: 1975-1986, 2004.

34. Singal R, Ferdinand L, Reis IM and Schlesselman JJ: Methylation of multiple genes in prostate cancer and the relationship with clinicopathological features of disease. Oncol Rep 12: 631-637, 2004.

35. Bastian PJ, Ellinger J, Heukamp LC, Kahl P, Muller SC and von Rucker A: Prognostic value of $\mathrm{CpG}$ island hypermethylation at PTGS2, RAR-beta, EDNRB, and other gene loci in patients undergoing radical prostatectomy. Eur Urol 51: 665-674, 2007.

36. Rogers CG, Gonzalgo ML, Yan G, Bastian PJ, Chan DY, Nelson WG and Pavlovich CP: High concordance of gene methylation in post-digital rectal examination and post-biopsy urine samples for prostate cancer detection. J Urol 176: 2280-2284, 2006.

37. Yates DR, Rehman I, Abbod MF, Meuth M, Cross SS, Linkens DA, Hamdy FC and Catto JW: Promoter hypermethylation identifies progression risk in bladder cancer. Clin Cancer Res 13: 2046-2053, 2007.

38. Pflug BR, Zheng H, Udan MS, D'Antonio JM, Marshall FF, Brooks JD and Nelson JB: Endothelin-1 promotes cell survival in renal cell carcinoma through the ET(A) receptor. Cancer Lett 246: 139-148, 2007.

39. Zhao YD, Springall DR, Hamid Q, Levene M and Polak JM: Localization and characterization of endothelin-1 receptor binding in the blood vessels of human pulmonary tumors. J Cardiovasc Pharmacol 26 (Suppl. 3): S341-S345, 1995.

40. Giaid A, Hamid QA, Springall DR, Yanagisawa M, Shinmi O, Sawamura T, Masaki T, Kimura S, Corrin B and Polak JM: Detection of endothelin immunoreactivity and mRNA in pulmonary tumours. J Pathol 162: 15-22, 1990.

41. Yang X, Liu L and Qi H: Study on endothelin-1 positive expression and quantitative analysis in lung cancer. Zhonghua Jie He He Hu Xi Za Zhi 21: 111-113, 1998. 